\title{
Law and Policy Dimensions of Ocean Governance
}

\author{
Pradeep A. Singh and Mara Ort
}

\section{Abstract}

Human populations have relied on the oceans for centuries for food supply, transportation, security, oil and gas resources, and many other reasons. The growing prospects of the oceans, such as access to marine genetic resources and seabed minerals, to generate renewable energy and as a potentially enhanced carbon sink, are contributing to increased interests to control and exploit the seas. At the same time, human pressure on the oceans, both from land- and atmospheric-based sources and at sea, as well as from climate change, has led to unprecedented levels of stress on the oceans. The concept of ocean governance has developed as a response to this. This chapter explores ocean governance from the interdisciplinary perspectives of law and human geography.

We trace the development of ocean governance from first practices and legal concepts up to the emergence of contemporary ocean governance in recent decades and explore how it departs from traditional practices. Zonal and sectoral approaches, as well as their underlying norms, are discussed. We then take a more critical stance to shed light on the role neoliberalism plays in the forming of ocean governance and the effects this paradigm can have on governance outcomes. The cases of fisheries management and ocean grabbing illustrate some possible mechanisms and effects. In addition, the role of commu-

\section{P. A. Singh $(\bowtie)$}

Faculty of Law, University of Bremen,

Bremen, Germany

INTERCOAST Research Training Group, Center for Marine Environmental Sciences (MARUM), Bremen, Germany e-mail: pradeep@uni-bremen.de

M. Ort ( $\square)$

artec Sustainability Research Center, University of Bremen, Bremen, Germany

INTERCOAST Research Training Group, Center for Marine Environmental Sciences (MARUM), Bremen, Germany

e-mail: ort@uni-bremen.de nities and indigenous people in ocean governance is discussed. Finally, the chapter addresses the shared or common concern surrounding the degradation of the marine environment, and the need for global and interdisciplinary cooperation in governing the oceans for mutual benefit.

\section{Keywords}

Marine environmental protection - Sustainable development $\cdot$ Common concern of humankind $\cdot$ Regime management and cooperation at sea - Governance tools . Local communities

\subsection{Introduction}

For centuries, the oceans have sustained life (both nonhuman and human), provided us with a host of nonliving resources, (renewable and nonrenewable), as well as fulfilled our transportation and recreational needs. Considering the vast importance of the oceans, it comes as no surprise that nations often demonstrate the desire to expand their sovereignty and gain control over the seas to exert control and dominance over it. In its centuries of development, the traditional law of the sea has witnessed the increased claim of state power and authority over marine spaces in a contested and competitive way. In recent decades, however, the global community started to realize the salient drawbacks from such a dominating approach - in particular, the depletion of living and nonliving marine resources as well as degradation of the marine environment. Thus, they declare in the United Nations Convention on the Law of the Sea 1982 (UNCLOS) that the "problems of ocean space are closely interrelated and need to be considered as a whole" (Preamble, UNCLOS 1982). 
The ocean governance discourse involves two presuppositions that renders it necessary to address ocean spaces and its uses in a holistic way. First, it acknowledges the existing and continuing division of ocean spaces (i.e., zonal/geographical aspect, in which maritime spaces are divided into zones that are subject to national jurisdiction and those beyond national jurisdiction) and the diverging regulations to control human activity in the oceans (i.e., sectoral/activity aspect, in which maritime activities are considered and regulated as a whole through regional or global regimes). Second, it strives to resolve governance problems arising from the zonal and sectoral aspects of the ocean spaces through a series of norms and tools implemented via increased cooperation and coodination across actors and institutions that operate within those spheres.

This chapter will discuss the concept of ocean governance - as the discourse is understood by lawyers and social scientists - and what that concept entails in terms of marine environmental protection. Specifically, this chapter traces the development of the concept in recent decades and explores how it departs from traditional practices where large parts of the seas were not subjected to national jurisdiction or any particular global or regional regime. In this context, it considers the zonal and sectoral aspects within the existing structure and its contribution toward achieving sustainable ocean governance. Next, this chapter will underscore a series of norms and tools that could bridge and harmonize the shortcomings arising from these realities. We then take a closer look at the role of neoliberalism as an influential hegemonic ideology in many parts of the world in the twentieth and twenty-first century that has left its traces in ocean governance, with examples from fisheries management and ocean grabbing. Furthermore, we touch upon the implications of ocean governance for local communities and indigenous people. Finally, this chapter ends by highlighting the importance of collaboration as an indispensable means to promote coherence in ocean governance.

\subsection{Ocean Governance: A Conceptual Development}

It is common knowledge that the oceans are fundamental to human life and our dependence on it continues to increase. This reliance necessitates international rules to govern the conduct of human activities in the oceans (Tanaka 2015a).

\subsubsection{Historical Development}

Before the twentieth century, the law of the sea was represented through a set of unwritten, customary rules that reflected the practice among states. The principle of freedom prevailed during this time, which meant that powerful mari- time states were able to make the most use of the oceans and its resources (Bederman 2014). In the early days, the high seas were understood as being common property, open to all (Mansfield 2004; WBGU 2013). However, there existed two competing concepts about who had sovereignty over the oceans: mare clausum versus mare liberum, both dating back to the seventeenth century. Mare clausum was the Portuguese notion of giving the rights over the ocean to the coastal states. In contrast, the Dutch notion of mare liberum defended the understanding of the freedom of the ocean. ${ }^{1}$ Both ideas were fueled by economic considerations: the Portuguese wanted to protect their role in trade, whereas mare liberum was developed by the Dutch jurist Hugo Grotius to establish the possibility of free trade for the Dutch East India Company (WBGU 2013). Over the centuries, many areas of the high oceans remained relatively open-access areas ("freedom of the seas"), whereas coastal waters were brought more and more under state control. The dawn of the twentieth century witnessed significant effort to codify the law of the sea (Harrison 2011). Alongside the emergence of new states, a greater balance between existing maritime powers and a shift in attention toward exploiting ocean resources for economic gains, the desire perceptibly swung toward establishing sovereignty or control over ocean resources while still maintaining the great freedom over navigation as previously enjoyed (since shipping remains an important interest for the maritime powers). Mainly from the 1950 s to the 1980s, the primarily open-access system of the oceans became a system where coastal states gained sovereignty rights and controlled and exploited the marine resources (Steinberg 2001). This development was fueled by the wish to extend national claims over offshore resources, as the role of oceans for resource provision was rising (United Nations 2012; WBGU 2013). In 1954, the United States extended their jurisdiction over the whole continental shelf of their coast, in order to extract resources (United Nations 2012). Consequently, many other states followed this example and expanded their areas from traditionally 3 nautical miles to 200 nautical miles to control larger parts of the sea and the seabed to be able to claim fish stocks, mineral deposits, and oil. These expansions of territorial control were first only covered by customary law (United Nations 2012b) without much coherence; thus, the need for more binding international laws was apparent (WBGU 2013). After decades of negotiating, the UNCLOS (United Nations Convention on the Law of the Sea), otherwise known as the "constitution of the oceans" (Koh 1982), was signed in 1982 and codified these arrangements. Consequently, the $200 \mathrm{~nm}$ zone became known as exclusive economic zone (EEZ, where states have the rights over all living and nonliving resources), and states could expand their

\footnotetext{
${ }^{1}$ However, this is an understanding based specifically on a Western organization of space and society - actual history is much more complex than just these two categories (see Steinberg 2001).
} 
sovereignty over parts of the continental shelf. The freedom of navigation, however, was mostly preserved.

\subsubsection{The Concept of Ocean Governance}

As the modern law of the sea is by itself not synonymous with ocean governance, it is useful to trace, within the design of the modern law of the sea, the development of "ocean governance" as a concept. In this context, Rothwell and Stephens (2016, pages 516-517) identify three significant phases in the development of the modern law of the sea that promotes ocean governance. During the first stage, starting from the early efforts to codify the law of the sea up until the adoption of four treaties in 1958, the focus was primarily on the desire of coastal states to exploit the resources of the ocean and not on crosscutting issues. Thus, although little heed was channelled toward advancing the protection of the marine environment, the seeds for the zonal and sectoral aspects of the law of the sea were established during this period. As the ocean spaces were divvied up into separate zones between nations, notably premised on the potential uses of these spaces, early steps were taken toward ascertaining who had jurisdiction over what. The second stage, from 1958 to 1982 , demonstrates the increasing awareness of states of the need to regulate human activity based on sectors (i.e., shipping, fisheries, minerals, and so on) and the need to advance the protection of the marine environment from degradation and pollution arising from those activities. To this end, several instruments, including the 1972 Stockholm Declaration on the Human Environment, were adopted. These developments had a telling effect on the commencement of the third phase. In the year 1982, the UNCLOS was finally concluded after years of heated negotiations. This development withdrew the focus from sovereignty, jurisdictional rights, and freedoms for individual states and put emphasis on shared responsibilities for the protection and preservation of the marine environment (Freestone 2008). Thus, UNCLOS provided the foundation for integrated management and governance of the oceans, supplemented by diverse treaties and soft law instruments (Rothwell and Stephens 2016).

In other words, while simultaneously respecting traditional rights (i.e., freedom of navigation) and emerging rights (i.e., sovereignty and sovereign rights over resources in areas within jurisdiction), the third and current stage of the modern law of the sea reflects the interests of which the concept of ocean governance seeks to secure. It is crucial to further state that the concept of ocean governance is intertwined with parallel developments in international environmental law and human rights law (in so far as they related to the oceans). As such, contemporary notions such as sustainable development are interwoven into the wider concept of ocean governance. Concurrently, the proliferation of international organizations, intergovernmental bodies, and other actors since the mid-twentieth century also represents this movement toward asserting greater protection measures of the marine environment (Singh 2018).

Gradually, within the twentieth century, the concept of ocean governance evolved. However, even though "in use" for quite a while already, it is not clearly defined but remains as a rather fuzzy term (Future Ocean and International Ocean Institute 2015). In some fields (e.g., social and political sciences), ocean governance comprises all rules, laws, institutions, and political measures regarding the oceans (Mondré and Kuhn 2017). These can include formalized or informal processes, as well as top-down or bottom-up approaches. Additionally, research focuses on governance-related issues like security and political strategies of nation-states (see, e.g., Humrich 2017; Wirth 2017) or investigates how economic interests shape policies (see, e.g., Mansfield 2004; Ritchie 2014). From a law perspective, however, the concept is narrower and usually relates to regulating maritime activities with a particular focus on marine environmental protection (Singh and Jaeckel 2018). From the latter perspective, there is great interest in how ocean governance involves cooperation and coordination across zones and sectors to harmonize (insufficient or ineffective) laws and policies adopted within those respective realms to pursue sustainable environmental management goals that benefit present and future generations. Thus, the concept of ocean governance, from a law perspective, can usefully be seen as the collective attempt to govern the conduct human activity in the oceans in a sustainable and orderly manner with the overall objective of conserving and protecting the marine environment. Further, while topics of regime fragmentation (such as regulatory gaps and duplicity of efforts) continue to surface, there are instances where this may not result in negative consequences. Given that the discourse of fragmentation and its bearings on ocean governance is a matter that deserves specific attention on its own, it will not be the focus of discussion here.

As the UNCLOS plays a critical role in setting the scene for ocean governance, it would be necessary to examine to what extent it actually caters for this purpose. The UNCLOS provides the foundational basis for state action to protect the marine environment. In Part XII of UNCLOS, 46 provisions are specifically dedicated toward environmental protection, requiring states (or international organizations) to adopt and enforce measures to protect the marine environment from the harmful effects of human activities, including land- and atmospheric-based sources of pollution that impair or degrade the oceans. Harrison (2017) eloquently explains that through this, the UNCLOS provides the foundational basis for marine environmental protection by determining, among others, the jurisdictional mandate to take such measures, followed by the general principles, substantive rules, and procedural rules vis-à-vis human activities at sea and the protection of the marine environment. 


\subsubsection{Zonal and Sectoral Aspects to Ocean Governance}

At this juncture, it is necessary to distinguish between the zonal and sectoral aspects in the modern law of the sea. As mentioned earlier, both these aspects are vital considerations in ocean governance. The zonal aspect simply refers to who possesses the mandate or the authority to prescribe regulations and enforce them (based on demarcated boundaries), whereas the sectoral aspect covers the type of activity sought to be regulated. As will be explained, jurisdiction in zones does not necessarily commensurate with sectors. This demonstrates that ocean governance is an intricate concept that requires addressing trans-boundary and cross-sectoral concerns.

In terms of zones, the manner in which the UNCLOS has carved out the oceans can generally be divided into two areas: areas within national jurisdiction and areas beyond national jurisdiction (Churchill and Lowe 1999). In the former category, UNCLOS recognizes several zones. In the territorial sea, which may extend up to 12 nautical miles from its baselines, coastal states enjoy sovereignty. ${ }^{2}$ Save for restricted rights (such as the right of innocent passage for ships to navigate through) that must be accorded to other states, ${ }^{3}$ the coastal state is free to exploit its living and nonliving resources, as well as to take measures to enforce its coastal security and environmental laws. ${ }^{4}$ The contiguous zone follows the territorial sea, which may be declared for up to 24 nautical miles, in order to allow the coastal state to take measures specifically pertaining to custom, fiscal, and sanitary issues and enforce regulations in its territorial sea. ${ }^{5}$ Apart from this, there exist another two other zones. Coastal states may declare an exclusive economic zone (EEZ), which may extend up to 200 nautical miles from its baselines, in which they have sovereign rights to exploit both living and nonliving resources for their own economic benefit. ${ }^{6}$ However, in contrast to the territorial sea, the coastal state has limited noneconomic rights in the EEZ. As such, other states enjoy certain freedoms, such as rights to navigation and laying submarine cables, provided that these activities do not prejudice the rights of the coastal state to reap economic benefits from the resources therein. ${ }^{7}$ Coastal states are also accorded sovereign rights to exploit and reap economic benefits from its continental shelf for up to 200 nautical miles and in some cases extending up to 350 nautical miles

\footnotetext{
${ }^{2}$ Articles 2-3, UNCLOS.

${ }^{3}$ Articles 17-19, UNCLOS.

${ }^{4}$ Article 21(1), UNCLOS.

${ }^{5}$ Article 33, UNCLOS.

${ }^{6}$ Articles 56-57, UNCLOS.

${ }^{7}$ Article 58, UNCLOS.
}

or beyond from its baselines. ${ }^{8}$ Within the areas in which it exercises sovereignty, coastal states have absolute discretion to enact regulations to protect the marine environment. In areas where they enjoy sovereign rights, coastal states have wide-ranging jurisdiction to promulgate environmental laws to protect their economic interest. ${ }^{9}$

Additionally, many coastal states also play a crucial role in ocean governance through the exercise of sovereign control over their ports. The UNCLOS and various instruments created through regional and global regimes have strengthened the ability of port states to enhance marine environmental protection, particularly in compliance and enforcement of numerous international standards and regulations. Although the UNCLOS recognizes the rights of landlocked states and their interest to gain access to the oceans and its living resources (i.e., fisheries) through neighboring coastal states (which is largely a matter of the latter's discretion), landlocked states play a limited role in ocean governance and the protection of the marine environment. Their contribution is restricted chiefly through the exercise of jurisdiction over ships that fly their flags and participation in global or regional regimes.

In areas beyond national jurisdiction, the UNCLOS recognizes two distinct zones. The first zone is the high seas here, in the water column that falls beyond the EEZ of any coastal state, all states enjoy numerous types of freedom, particularly with respect to fisheries (it will be recalled that all states enjoy certain freedoms, e.g., navigation, even within the EEZ of coastal states). ${ }^{10}$ Pertinently, since it belongs to no one, no particular state has the jurisdiction to enact specific legislation, be it environmental or otherwise, in this zone. However, this does not mean that the entire high seas area is subject to lawlessness or anarchy. The flag state, i.e., the state to which the ship is registered, exercises jurisdiction over the ship flying its flag and the activity it carries out in the high seas. ${ }^{11}$ Thus, ships are bound to the domestic legislation of their flag states, as well as other regulations to which that state decides to adopt at the international level. ${ }^{12}$ The second zone created by the UNCLOS, the international seabed area, is simply known as the "Area" ${ }^{13}$ It encompasses the seabed area that falls beyond the continental shelf area claimed by any coastal state and declares it as the "common heritage of mankind." ${ }^{14}$ In the Area, the International Seabed Authority (ISA) is given the mandate, pursuant to UNCLOS,

\footnotetext{
${ }^{8}$ Article 76, UNCLOS.

${ }^{9}$ Article 193, UNCLOS.

${ }^{10}$ Article 87, UNCLOS.

${ }^{11}$ Articles 91-92, 94, UNCLOS.

${ }^{12}$ Articles 116-117, 119, UNCLOS.

${ }^{13}$ Article 1(1)(1), UNCLOS.

${ }^{14}$ Article 136, UNCLOS.
} 
to regulate the exploration and exploitation of nonliving resources, i.e., minerals, as well as to take necessary measures to protect the marine environment from the harmful effects of such activities. ${ }^{15}$ As UNCLOS only prescribes a skeletal framework for the deep seabed mining regime, the ISA is specifically given the task to progressively develop detailed regulation. ${ }^{16}$ Hitherto, three separate regulations for the exploration of mineral resources (specifically for polymetallic nodules, polymetallic sulfides, and cobalt-rich ferromanganese crusts) are in existence. Regulations for the exploitation of mineral resources are currently at an advanced draft stage (Brown 2018), and work to design a benefitsharing mechanism is expected to commence in due course.

Moving from the zonal aspect to the sectoral aspect, the latter recognizes the fact that assigning jurisdiction to create environmental regulations premised on boundary lines is inadequate and needs to be complemented with laws that specifically apply to the activity in concern. As such, the modern law of the sea involves numerous sectoral regimes, e.g., fishing, shipping, mining, and recreational, subjecting each of them to separate sets of laws. The need for sectoral regulation becomes particularly obvious in trans-boundary scenarios. For example, shipping activities typically involve the crossing of multiple jurisdictions, including the high seas, and as such need to be regulated more delicately. Similarly, fishing and mining activities taking place in an adjacent area will inevitably affect, cumulatively, the marine environment of surrounding areas and impair the ability of others to meaningfully exercise and enjoy their rights (Markus and Singh 2016). As such, the sectoral aspect of the modern law of the sea has contributed to the proliferation of international organizations with carefully defined mandates to regulate particular activities (Harrison 2015). This includes, among others, the ISA to govern mineral mining activities in the Area, the International Maritime Organization (IMO) to regulate global shipping activities, the Fisheries and Agriculture Organization (FAO) to promote sustainable fisheries measures, and the International Whaling Commission (IWC) to control whaling activities. The functions and responsibilities of these international organizations are typically defined in international treaties signed by states, thereby giving them the mandate to create regulations or guidelines that would apply to their respective sectors or regimes (Harrison 2011). Regional regimes, particular in the case of fisheries, are also fast-growing, as can be seen in the number of Regional Fisheries Management Organizations (RFMOs) and Regional Seas Programs (RSPs) that are currently in existence (Singh 2018).

\footnotetext{
${ }^{15}$ Articles 1(1)(2), 137, 145, 150, 153 and Annex III, UNCLOS

${ }^{16}$ See Part XI and Annex III of the UNCLOS.
}

The above demonstrates that the jurisdictional mandate to regulate human activities at sea - specifically, to adopt necessary measures to protect the marine environment - is a critical consideration in the ocean governance discourse. This section also shows that, because a multitude of actors and institutions are involved in regulating human activities at sea - who often work independently and in isolation from each other - and compounded by the fact that the problems of the oceans are interconnected and interdependent, ensuring coherence in environmental protection is a complex and delicate subject. As such, there is a pressing need for a more effective response to the cumulative effects of human activities (and natural phenomena) to the marine environment (Scott 2015) - i.e., the raison d'être of the concept of ocean governance. To this end, reliance on a wide selection of norms and tools that are increasingly gaining recognition under international law, to assist in overall policy- and decision-making processes, goes a long way in contributing to the concept of ocean governance.

\subsection{Norms and Tools Pertaining to Ocean Governance}

The theme of ocean governance comprises of an array of norms and tools that serve to realize its objectives. At the outset, it would be useful to clarify what "norms" and "tools" mean in this context. By "norms," reference is generally made to legal principles, concepts, and doctrines that are recognized under international law (De Sadeleer 2002). Their normative values differ from one to another and depend, inter alia, on how they are perceived as binding (or merely as guiding) in practice by states and international organizations or as interpreted by international courts and tribunals (Tanaka 2015b). Under certain scenarios, non-binding norms may have a compelling effect (Winter 2018). However, as this chapter is not focused on ascertaining the exact status of these principles, doctrines, or maxims, the term "norms" is used generically here to refer to the handful of notions that apply to ocean governance. Concerning "tools," reference is made to the various measures and strategies designed with the aim to protect the marine environment from human activities at sea. In other words, "tools" here refer to the means that are adopted or deployed to attain the desired end. In the context of ocean governance, "tools" are both supplementary and complementary to "norms" and analogous in certain circumstances (Singh and Jaeckel 2018). In fact, the continuous and persistent practice of adopting certain measures or approaches, as a rule of thumb, may evince the normative value of a "tool." For instance, environmental impact assessments can be seen as a tool, in as much as it is an accepted norm or principle of international law. 


\subsubsection{Norms Pertinent to Ocean Governance}

Here, several norms that are relevant to the concept of ocean governance will be discussed. They comprise of the following: the "no-harm" or prevention of trans-boundary harm rule, environmental impact assessments, the precautionary approach, the ecosystem-based approach, sustainable development, and the polluter pays principle. One specific norm, the principle of cooperation, deserves special attention and will be considered later. This list is by no means exhaustive in the ocean governance discourse. Nevertheless, they have been selected for the present discussion because they either are grounded in the UNCLOS and other related agreements or have received significant acknowledgment and treatment by international and regional organizations. As such, they possess a certain degree of authoritative value and require specific consideration in decision-making processes as it has some bearing on the legitimacy of those outcomes.

The "no-harm" or prevention of trans-boundary harm refers to the obligation of states to ensure that activities within their jurisdiction or control do not cause significant harm to the environment of other states. In other words, states must ensure that the activities which they conduct, or which they permit, sanction or allow, are conducted in a manner that is environmentally sound, and that appropriate preventive measures are taken to ensure that the environmental harm arising from those activities are minimized - particularly if it is likely that such harm would be trans-boundary. It should be emphasized that this obligation is one of conduct and not of effect; it does not prohibit harmful effect in a strict or absolute sense, i.e., states are only liable for transboundary harm if they fail to exercise due diligence in controlling the activities (Birnie et al. 2009). The UNCLOS expressly affirms this obligation in the marine environment context. ${ }^{17}$

Environmental impact assessments (EIA) involve the practice of ascertaining the potential environmental effects of an activity prior to its conduct. This also extends to the requirement to monitor the environmental effects of the activity continuously throughout its life and upon cessation. ${ }^{18}$ In this sense, while the practice of preparing an EIA is more appropriately seen as a tool to ensure adherence to the "no-harm" rule, its prevalence as a global practice in recent times has elevated its status to a customary rule of international law. Consequently, the absence of a proper EIA to ascertain the environmental harm of an activity, particularly

\footnotetext{
${ }^{17}$ Article 194, UNCLOS.

${ }^{18}$ See the Pulp Mills on the River Uruguay (Uruguay v. Argentina) case, Judgment of 20 April 2010, International Court of Justice, available at: http://www.icj-cij.org/files/case-related/135/135-20100420-JUD-0100-EN.pdf.
}

where it is likely to cause trans-boundary harm, may be seen as a failure of the due diligence threshold and attract responsibility under international law (Birnie et al. 2009). Similarly, the UNCLOS also prescribes the requirement to conduct EIAs and continuously monitor the environmental effects of activities at sea. ${ }^{19}$

The precautionary approach, at its core, advocates for the exercise of caution in the face of uncertainty. More precisely, it excludes the reliance on lack of scientific certainty as a basis for inaction in adopting cost-effective measures to protect the environment. In other words, environmental threats should be effectively addressed even if the scientific certainty of the extent and effect of the threat is in question. A more contemporary interpretation goes further and requires that potentially harmful activities should be postponed until there is sufficient and reliable scientific verification that the potential environmental harm arising from its conduct can be convincingly averted or managed (Marr 2003; Jaeckel 2017).

Similar to the precautionary approach, the ecosystembased approach also has its foundation rooted in science. Essentially, the ecosystem-based approach concentrates on "the protection of the ecosystem itself, including the structure, processes and functions of the community of biological organisms, and the interactions between them as well as between them and non-living components within a particular marine area" (Singh and Jaeckel 2018, page 624). Adopting this approach enables decision-makers to consider the cumulative impacts of human activities at sea on marine ecosystems in determining whether to permit a particular activity or not. The ecosystem-based approach closely resonates with the precautionary approach, and they both complement each other (Trouwborst 2009).

Sustainable development as a concept requires economic considerations to be weighed alongside social and environmental considerations in the context of development. It recognizes that economic progress involves certain detriment to the environment but is necessary for social development. At the same time, it is equally clear that under certain scenarios, the need to protect and preserve the environment may prevail over economic or social considerations (Tanaka 2015b). The sustainable development discourse has embraced the oceans, as can be seen in the Sustainable Development Agenda of 2030 and the Sustainable Development Goals of 2015 ("the SDGs") as adopted by the United Nations General Assembly in 2015. ${ }^{20}$ SDG 14 (life below water) is specifically dedicated to the oceans and calls on states to "conserve and sustainably use the oceans, seas and marine resources for sustainable

\footnotetext{
${ }^{19}$ Articles 204-206, UNCLOS.

${ }^{20}$ Resolution A/Res/70/1, Resolution adopted by the General Assembly on 25 September 2015, available at: http://www.un.org/ga/search/view_ doc.asp?symbol=A/RES/70/1\&Lang $=\mathrm{E}$.
} 
development."21 It follows that, while the aspiration of states to develop progressively is valid and fundamental, marine development policies should not be carried out at the rapacious expense or in completed disregard of the marine environment. Also embedded in the proper implementation of this concept is the requirement to consider alternatives to prospective or ongoing projects, and even to exercise forbearance if the harm to the marine environment is demonstrably significant.

Finally, the polluter pays principle entails the requirement for the operator of the activity that causes harm to the environment to make the necessary reparations to address that damage. Effectively, this means that the operator of the activity is responsible to undertake restoration measures or to compensate for the harm caused to the environment. This should not be seen as consideration for a license to pollute or to deplete resources but rather as a basis to internalize those environmental costs (which would otherwise be treated as an externality) to ensure that profits are not made at the expense of the environment (Beder 2006).

\subsubsection{Tools Pertinent to Ocean Governance}

As mentioned earlier, some of the norms discussed above also take the form of tools, in so far as they are capable of serving as a means to advance the effective protection of the marine environment. In addition, several other measures or instruments may be adopted to give effect to the said norms. This includes environmental policy mechanisms and areabased management tools (ABMTs), including strategies such as maritime spatial planning (MSP) and marine protected areas (MPAs).

Environmental policy mechanisms involve the designing of internal policy mechanisms within states or regimes to ensure that marine environmental considerations are effectively taken into consideration in decision-making processes. This includes the setting up of scientific advisory bodies within the institutional setup as well as prescribing procedures to facilitate the flow of technical expertise into decision-making processes, as well as the use of incentives to promote technological advances or the adoption of higher environmental standards than that imposed by the regulator. Environmental strategies should be drawn up, providing for transparent decision-making processes, and include opportunities for stakeholder and public participation.

As the name suggests, ABMTs are area-specific and would suit as a perfect combination for the ecosystem-based

\footnotetext{
${ }^{21}$ Sustainable Development Goals (SDG 14), United Nations Department of Economic and Social Affairs (UN-DESA), Division for Sustainable Development Goals, accessible at: https://sustainabledevelopment.un.org/sdg14
}

approach. The MSP strategy, on the one hand, is premised on the fact that the stresses caused by human activities on the marine environment can be geographically mapped, thereby providing some useful indication on the vulnerabilities of that specific area to particular types of harm (Zacharias 2014). This enables decision-makers to permit activities in areas that are resilient enough to withstand (and recover from) the associated environmental harm and, conversely, to restrict activities in areas that are already subject to high levels of stress and would struggle to recover from the ensuing consequences of such activities (Markus et al. 2015). The creation of MPAs, on the other hand, is essentially a measure to protect certain areas (of environmental interests) from certain activities, such as shipping, fisheries, or mineral exploitation. This includes areas that have sensitive and fragile ecosystems, whether thriving or in despair, and breeding ground areas (Halpern et al. 2010). More importantly, ABMTs allow for cumulative effects (i.e. not only immediate impacts from the particular activity in concern, but the impacts arising from other related activities and natural causes) to be considered when determining the areas that require protection. However, due to regulatory gaps and the fragmentation nature of governance arising from the zonal and sectoral approach, states and competent organizations only have the mandate to designate MPAs in areas where they exercise jurisdiction or only concerning the activity it is tasked to regulate, respectively.

\subsection{Critical Discussion of Ocean Governance}

As reflected from the above, the oceans are not only diverse ecosystems; they are also economic and political spaces. In this fluid and boundary-less environment, diverse interests are articulated by nation-states, organizations, companies, local communities, and indigenous people. In this context, it seems obvious that ocean governance is a conflicting area (Vince 2014). To mediate these interests, various tools of ocean governance are applied. However, ocean governance does not develop in a neutral arena, as the previous section has shown. Rather, it is influenced by dominant rationalities. In the first part of this section, we focus on neoliberalism as a main normative foundation for many governance decisions in the last decades (Peet et al. 2011). The dominance of economic considerations over other issues, or the belief that the market mechanisms also help to solve environmental problems, however, leads to challenges and gaps in regard to communities' and indigenous peoples' needs and concerns. A closer look at these issues will form the second part of this section. Particularly, while we do not wish to undermine the importance of ocean governance as a concept, we would like to sensitize that there can also be problematic developments, which have to be investigated critically. 


\subsubsection{Neoliberalism and Property Rights as a Form of Ocean Governance}

Even though ocean governance is often promoted by national agencies and international organizations under the premise of environmental protection, market forces also influence the setup of tools and norms. As observed earlier, in the last century, there was a move away from open access and freedom of the seas not only to national control of the oceans but also to the privatization of their resources (Mansfield 2004). Since the 1950s, a new political economy of the oceans emerged, with the question of the commons being a central one (Mansfield 2004). Mansfield identifies neoliberalism as a dominant form of ocean governance (Peet et al. (2011) observed this for trend in environmental governance in general). Using fisheries as an example, Mansfield outlines how a specific form of neoliberalism developed in ocean governance over the last 60 years. Often, there is a belief in neoliberalism as a helpful explanation as well as remedy in environmental governance: conservation is ineffective due to market failure, and market mechanisms will lead to more efficient environmental solutions in comparison to state-lead initiatives. Through the assignment of property rights and privatization, markets are created to govern the access to and use of ocean resources (Mansfield 2004). Neoclassical and neoliberal economists believe that economic efficiency will ultimately lead to social and environmental welfare as well (Mansfield 2004). In this tradition, conventional approaches like Gordon (1954) assume that market rationality is natural and that a lack of property rights leads to economic and environmental problems. In this argumentation, there are many parallels to the often repeated and much contested so-called tragedy of the commons by Hardin (1968), published 14 years later (for a contrary view see, e.g., Ostrom et al. 1999). Also, the German Advisory Council on Global Change adopts this notion and discusses how, without strong rules, a rationality of exploitation would prevail and free riders would enrich themselves at the cost of the community (WBGU 2013). Concerning fisheries specifically, Mansfield outlines Gordon's (1954) argumentation that "without property regimes that constrain individual behavior, people will overcapitalize and overuse resources because it is economically rational to do so" (Mansfield 2004, page 319). The problem of overfishing and overcapitalization is seen in the open-access regime and missing property rights. Commons are distinguished from open access in that they are managed through informal institutions, arrangements, etc. and therefore present a form of property rights. However, the underlying economic approach is not challenged, and critical voices on the economic backdrop and assumptions are not widely spread (Mansfield 2004). Critical research reviewed by Mansfield does not see the problem in the lack of property rights but in power relations established through colonialism, capitalism, and global markets (Mansfield 2004). Rather than applying economic models on ocean governance, it might be more helpful to investigate power relations that lead to the problems that have to be solved (i.e., overfishing, pollution, war). The following two case studies illustrate some of the problems that can arise from incorporating a neoliberal paradigm in ocean governance systems.

\subsubsection{The Case of Fisheries and Quota Management Systems}

Even though neoliberalism has the basic principle that the state should not interfere with the market, it still relies on the state to create and maintain property rights. These property rights are a form of enclosure (and therefore can enable primitive accumulation), which then allow privatization (Mansfield 2004). Regarding fisheries, market incentives are created as property is defined as the right to fish (Mansfield 2004). One mechanism is, for example, the individual transferable quota system (ITQ) to marketize the allocation of fish catch. Once publicly accessible, fishing grounds are now restricted to the use of a small group of companies and individual fisherpersons. Through privatization and commodification, a new market is created (Mansfield 2004). ITQs are "strong quasi-property rights" (Hersoug 2018, page 101). Hersoug assesses ITQ systems critically, using the example of Aotearoa New Zealand. In Aotearoa New Zealand, a Quota Management System (QMS) was introduced in 1984, during a neoliberal economic restructuring as a response to crowded and overfished inshore fisheries (Hersoug 2018). The market should regulate the situation. However, the system is still dependent on strong government regulations and is mainly managed in a top-down approach (Hersoug 2018). Government interventions are also important to cater for the interests of all stakeholders, as ITQs privilege just the groups that have a share. The research outlines how the introduction of QMS led to the exclusion of small-scale fishers, many of them being Maori (indigenous people of Aotearoa New Zealand) (Hersoug 2018). Even though Maori were included in the QMS process and got a share which was celebrated as a big success, the system failed in really enabling community participation, and no "trickle-down" effects, e.g., in terms of employment, could be observed (Hersoug 2018).

Hersoug is therefore quite critical of market-based solutions like the Quota Management System. He observes hardly any outcomes in terms of better stewardship for the environment: "ITQ solutions have not contributed to increased sustainability, neither in biological nor in social terms" (Hersoug 2018, page 109). Even though QMS and similar solutions do not solve all problems, they were recommended by most fisheries economists, as property rights were seen as an incentive for sustainable fisheries. Hersoug 
suggests that besides defining rights, also obligations should be formulated. Additionally, the marine environment should be framed as a public resource (Hersoug 2018).

\subsubsection{The Case of Ocean Grabbing}

When talking about property rights about ocean areas and resources, also the issue of ocean grabbing has to be mentioned. That ocean governance does not always only promote sustainable development but can also lead to (unintended) negative outcomes, e.g., for local communities, is discussed by several authors (Benjaminsen and Bryceson 2012; Bennett et al. 2015; Hill 2017). Bennett et al. (2015) refer to "ocean grabbing" as a process within which access and rights to marine resources and spaces are reallocated. This can happen through enclosure, appropriation, and disposession (Hill 2017). Ocean grabbing is described as "actions, policies, or initiatives that deprive small-scale fishers of resources, dispossess vulnerable populations of coastal lands, and/or undermine historical access to areas of the sea" (Bennett et al. 2015, page 61). Ocean grabbing can happen both intentionally and unintentionally and be conducted by private as well as state actors. Also, measures of ocean governance can lead to ocean grabbing. Zoning, the creation of MPAs or fisheries policies, can deprive local communities of resource use and access and lead to privatization or enclosure of marine resources and areas (Bennett et al. 2015) - at the cost of former custodians and in favor of more powerful actors (Hill 2017). In a case study in Malaysia, Hill (2017) found that through the establishment of a marine park, no-take zones were installed that divorce fisherpeople from their means of production. The protected areas now serve as "raw material" for capitalist production, to the benefit of state officials as well as commercial tourist operators. The local population was not included in the decision-making process prior to the establishment of the park. While the protection of our oceans still remains an essential goal, the social impacts of marine conservation have to be considered (Hill 2017).

\subsubsection{Communities and Indigenous People and Ocean Governance}

When dealing with laws, conventions, policy documents, and so on, it should not be forgotten that these decisions and rules have effects not only in an abstract way but can also affect the livelihoods of local communities and indigenous people in both positive and negative ways (Davies et al. 2018). This is especially problematic when governance tools are set up in a top-down manner and no real discussion is possible (Ritchie 2014).

Marine spatial planning and marine protected areas were discussed above as tools of ocean governance. In their research on marine spatial planning (MSP), Boucquey et al.
(2016) analysed fisheries in the United States. They focus on the representation of communities in the setting up of the programs. Generally, Boucquey et al. (2016) found that management usually focuses on economic activities and does not take into account "the complex ways fishing communities are socially and emotionally integrated with marine species" (Boucquey et al. 2016, page 4). Rather, these interactions become simplified during the planning process. Communities are labelled and categorized, and this "data" is fed into the data system by "experts" such as planners or researchers. According to Boucquey et al., the narratives surrounding MSP and MPAs promote stabilization, categorization, and organization as a means to improve ocean management (Boucquey et al. 2016). This is underlined by the call for more scientific data and knowledge, which is understood to enable more efficient and effective governance (see, e.g., WBGU 2013). This will have the result that so-called expert knowledge shapes how oceanic actors are portrayed.

The movement toward MSP can also be understood as a proceeding neo-liberalization of nature, enforced through enclosure and exploitation (Boucquey et al. 2016). Ritchie (2014), for example, found in her research on MSP in the United Kingdom that there is a supremacy of economic development and the overarching goal to maximize economic growth. The mapping of oceans for particular users and uses during MSP processes sets up "the potential for ocean enclosures to privilege the most powerful actors" (Boucquey et al. 2016, page 2). These are seldom local communities or indigenous people, but rather large companies and nation-states (the ones with the biggest stake), a problem also perceived by Ritchie (2014).

Even though for the high seas outside of national jurisdictions, it might make sense to aim for overarching and general governance and even top-down solutions, local communities might get more out of small-scale, local, and bottom-up solutions, which are potentially also more sustainable. Stephenson et al. (2014, page 264) called for place-specific, local solutions rather than "top-down, one-size-fits-all policy solutions" that tend to "fail to achieve sustainable outcomes."

Participation and inclusion in decision-making is not only an issue concerning local communities in general but also indigenous peoples in specific. Indigenous peoples often have a deep cultural connection to the ocean. According to a report by the United Nations (United Nations Economic and Social Council 2016), they rely on oceans for food, health, economic activities, and cultural practices. Generally, many indigenous peoples do not distinguish so much between land and ocean; in their worldview all is one and connected (Nursey-Bray and Jacobson 2014; United Nations Economic and Social Council 2016). In addition, indigenous peoples often do not have access to traditional resources anymore; they were deprived of rights and access to resources during the colonial period and can also be affected by more recent 
governance processes (Stephenson et al. 2014). However, there is not much research on indigenous people involvement in MPA governance and management, as a literature review carried out by Ban and Frid (2018) found. They point to literature on ocean grabbing to show the contested nature of MPAs as places where conservation initiatives or the establishment of MSP or MPAs can deprive local communities of resources and/or undermine access to areas (Bennett et al. 2015). Traditional governance systems in postcolonial states were dominated by colonial forms of governance (NurseyBray and Jacobson 2014). In this regard, there is a "historical and ongoing collision between Western (and colonial) systems of law and governance and Indigenous modes of law and governance" (Nursey-Bray and Jacobson 2014, page 29).

In the UN study on the relationship between indigenous peoples and the Pacific Ocean, the authors state that generally indigenous people are not well included in decisionmaking for a like the UN organizations (United Nations Economic and Social Council 2016). Yet, the report finds that "[...] their [indigenous peoples of the Pacific] ability to meaningfully participate in decision-making on matters that will have a direct impact on oceans and their environments is limited" (United Nations Economic and Social Council 2016, page 3).

The situation in Aotearoa New Zealand provides another example. Customary fishery rights eroded during the colonial period (Bess and Rallapudi 2007). When a QMS was about to be established, many iwi (Maori tribes) objected to it due to concerns that even more rights would be alienated from them. Settlements (1992 Fisheries Deed of Settlement and Treaty of Waitangi (Fisheries Claims) Act 1992) found that Maori customary fishing rights had not extinguished (Bess and Rallapudi 2007). Specific legislation was passed to protect customary fishing rights (i.e., Taiapure areas, Mataitai reserves) (Bess and Rallapudi 2007). However, these are relatively small in size and number, and due to the lengthy and complicated establishment process, many Maori groups shy away from applying for them.

The examples in this section show that global trends, developments, and decisions have effects on local population, and these social and cultural impacts have to be taken into account in policy-making. In our opinion, especially the adoption of market mechanisms to ocean governance is problematic. Also, ocean governance is not independent from or free of hegemonic paradigms, norms, and political power structures. A thorough look is necessary to find out who is winning and who is losing from specific governance decisions and their complex effects. Taking that into account might lead to a more comprehensive analysis of ocean governance, as well as to more just decision-making processes and more sustainable outcomes.

\subsection{Overcoming the Obstacle: Cooperation to Address a Common Concern and the Importance of Marine Scientific Research}

As seen from the above, there are ample ways in which the oceans can be governed in a more orderly and sustainable manner. The adoption of ABMTs and other environmental strategies, for instance, can provide positive results over a short period (Hilborn and Ovando 2014). However, the primacy of the zonal and sectoral aspects to marine governance within the law of the sea sphere limits the potential of such measures, simply because states and international organizations are only empowered to act within their respective jurisdictions and mandates. To overcome this obstacle, two initiatives are relevant. First, there is a need for enhanced cooperation and coordination among states, between states and international/regional organizations, and among international/regional organizations. Industry and other private actors also need to feature in this setup (Singh 2018). Second, it is essential to view the protection of the marine environment as a shared concern or a "common concern of humankind," in which all subjects of international law have a legitimate interest in ensuring (Harrison 2017). Thus, any form of activity taking place in the ocean spaces of any jurisdiction is a matter of shared concern if it causes significant harm to the marine environment. Furthermore, this not only includes activities at sea but also extends to the pollution of the marine environment from land-based sources and from or through the atmosphere. ${ }^{22}$

There is some evidence to indicate that the first initiative is gaining traction. The proliferation of regional management regimes in different geographic areas with extraterritoriality jurisdiction illustrates that states are amenable to work together to resolve common concerns. Furthermore, the increased number in agreements to cooperate signed between international organizations signal that global and regional institutions are beginning to discover ways to harmonize the segregated regulation of activities within their respective sectors and to share their expertise. The involvement of industry within the setup of these organizations is also encouraging, as it ensures the wide acceptance of the results or outcomes of these internal processes. However, it should be noted that the proliferation of regional agreements and arrangements per se does not necessarily result in actual improvements, particularly where levels of compliance is low, enforcement is lax, or where nonparties and outliers to the arrangements remain active in the geographic area and undermine conservation efforts.

The second initiative is particularly troublesome due to the complications arising from sovereignty and sovereign rights. As states are entitled to explore and utilize the ocean

\footnotetext{
${ }^{22}$ Articles 207 and 212, UNCLOS.
} 
resources within their jurisdiction pursuant to their domestic policies and interests, it is difficult for other states to intervene. Nevertheless, if the obligation to protect and preserve the marine environment is seen as an erga omnes obligation, this might encourage concerned states to commence dispute resolution proceedings against a delinquent state (Harrison 2017). As the dispute resolution process under the UNCLOS is mandatory, member states arguably have a recourse to compel other states to be more attentive toward marine environmental protection. It would be interesting to see how this plays out in the future, particularly in the light of the common but differentiated responsibility precept, which accepts that developing states are not legally required to adopt at par environmental measures as developed states.

\subsection{Conclusion}

This chapter describes ocean governance as a concept that embraces the sustainable and inclusive management of the oceans across the various maritime zones and sectoral divisions. It demonstrates the applicability of various norms and tools to advance different objectives in ocean governance and particularly promulgates the need to enhance cooperation across the multiple actors and institutions that participate in activities at sea. It should also have become clear that ocean governance is by no means a narrowly defined area, both within and across disciplines. This underlines the importance of interdisciplinary cooperation among different strands of research, e.g., law and human geography, as well as social sciences and natural sciences in general, to foster mutual understanding. In writing this chapter, we became even more conscious of the different approaches and perspectives adopted by our respective disciplines when dealing with the issue of ocean governance. Therefore, the goal of the chapter was not to circumscribe a common position but rather to emphasize topics in ocean governance that are important to us from our specific standpoints. We think that interdisciplinary approaches in research could help to improve analysis as well as the development of ocean governance, as perspectives from other disciplines might shed new light on many topics.

Obviously, different disciplines ask different questions. An integration of different forms of knowledge could therefore help to develop a more holistic perspective and address concerns that are not presently considered by any single discipline. For instance, although we did not touch upon it in this chapter, future research could benefit from a stronger inclusion of economic perspectives in the ocean governance discourse. Even if the application of economic mechanisms in fields like conservation is often disputed, it is necessary to critically consider the perspective of economists to have a truly comprehensive picture. Additionally, issues of partici- pation and transparency in decision-making and agendasetting (and the underlying power relations) at all levels also deserve attention from future research. After all, the success of realizing the Sustainable Development Goals, particularly SDG 14, largely hinges on successful local and regional level initiatives.

By viewing the protection of the marine environment as a common concern of humankind, in which we need representation of various disciplines, this chapter calls for greater coordination and coherence in a large shared area with competing claims and conflicting uses. Such an approach is critical in ensuring the rational and sustainable use of the oceans and its resources to meet current and future demands as well as interests.

\section{Appendix}

This article is related to the YOUMARES 9 conference session no. 4: "Law and Policy Dimensions of Ocean Governance." The original Call for Abstracts and the abstracts of the presentations within this session can be found in the Appendix "Conference Sessions and Abstracts", Chapter "3 Law and Policy Dimensions of Ocean Governance", of this book.

\section{References}

Ban NC, Frid A (2018) Indigenous peoples' rights and marine protected areas. Mar Policy 87:180-185

Beder S (2006) Environmental principles and policies: an interdisciplinary introduction. Earthscan, London

Bederman DJ (2014) The Sea. In: Fassbender B, Peters A, Peter S (eds) The Oxford handbook of the history of international law. Oxford University Press, Oxford, pp 359-382

Benjaminsen TA, Bryceson I (2012) Conservation, green/blue grabbing and accumulation by dispossession in Tanzania. J Peasant Stud 39(2):335-355

Bennett NJ, Govan H, Satterfield T (2015) Ocean grabbing. Mar Policy 57:61-68

Bess R, Rallapudi R (2007) Spatial conflicts in New Zealand fisheries: the rights of fishers and protection of the marine environment. Mar Policy 31(6):719-729

Birnie P, Boyle A, Redgwell C (2009) International law and the environment, 3rd edn. Oxford University Press, Oxford

Boucquey N, Fairbanks L, St. Martin K et al (2016) The ontological politics of marine spatial planning: assembling the ocean and shaping the capacities of 'Community' and 'Environment'. Geoforum 75:1-11

Brown C (2018) Mining at 2,500 fathoms under the sea: thoughts on an emerging regulatory framework. Ocean Sci 53(2):287-300

Churchill RR, Lowe AV (1999) The Law of the Sea, 3rd edn. Manchester University Press, Manchester

Davies K, Murchie AA, Kerr V et al (2018) The evolution of marine protected area planning in Aotearoa New Zealand: reflections on participation and process. Mar Policy 93:113-127

De Sadeleer N (2002) Environmental principles: from political slogans to legal rules. Oxford University Press, Oxford 
Freestone D (2008) Principles applicable to modern oceans governance (editorial). Int J Mar Coastal Law 23(3):385-391

Future Ocean and International Ocean Institute (2015) Sustainable use of our oceans - making ideas work. Maribus, Hamburg

Gordon HS (1954) The economic theory of a common-property resource: the fishery. J Political Econ 62(2):124-142

Halpern BS, Lester SE, McLeod KL (2010) Placing marine protected areas onto the ecosystem-based management seascape. Proc Natl Acad Sci U S A 107(43):18312-18317

Hardin G (1968) The tragedy of the commons. Science 162(3859):1243-1248

Harrison J (2011) Making the law of the sea: A study in the development of international law. Cambridge University Press, Cambridge

Harrison J (2015) Actors and institutions for the protection of the marine environment. In: Rayfuse R (ed) Research handbook on international marine environmental law. Edward Elgar Publishing, Cheltenham, pp 57-80

Harrison J (2017) Saving the oceans through law: the international legal framework for the protection of the marine environment. Oxford University Press, Oxford

Hersoug B (2018) "After all these years" - New Zealand's quota management system at the crossroads. Mar Policy 92:101-110

Hilborn R, Ovando D (2014) Reflections on the success of traditional fisheries management. ICES J Mar Sci 71(5):1040-1046

Hill A (2017) Blue grabbing. Reviewing marine conservation in Redang Island Marine Park, Malaysia. Geoforum 79:97-100

Humrich C (2017) The Arctic Council at twenty: cooperation between governments in the global Arctic. In: Conde Pérez E, Iglesias Sanchez S (eds) Global challenges in the Arctic Region: sovereignty, environment, and geopolitical balance. Routledge, London, pp 149-169

Jaeckel A (2017) The International Seabed Authority and the precautionary principle: balancing deep seabed mineral mining and marine environmental protection. Brill, Leiden

Koh TTB (1982) A constitution for the Oceans, remarks by Ambassador Koh of Singapore, President of the Third United Nations Conference on the Law of the Sea, available at http://www.un.org/Depts/los/convention_agreements/texts/koh_english.pdf. Accessed 8 June 2018

Mansfield B (2004) Neoliberalism in the oceans: "rationalization," property rights, and the commons question. Geoforum 35(3):313-326

Markus T, Singh P (2016) Promoting consistency in the deep seabed: addressing regulatory dimensions in designing the international seabed authority's exploitation code. Rev Euro Comp Int Environ Law $25: 347-362$

Markus T, Huhn K, Bischof K (2015) The quest for seafloor integrity. Nat Geosci 8:164-165

Marr S (2003) The precautionary principle and the law of the sea: modern decision-making in international law. Brill, Leiden

Mondré A, Kuhn A (2017) Ocean Governance. In: Bundeszentrale für Politische Bildung (ed) Meere und Ozeane. Aus Politik und Zeitgeschehen 51-52:4-9

Nursey-Bray M, Jacobson C (2014) 'Which way'?: the contribution of Indigenous marine governance. Aust J Maritime Ocean Aff 6(1):27-40
Ostrom E, Burger J, Field CB et al (1999) Revisiting the commons: local lessons, global challenges. Science 284(5412):278-282

Peet R, Robbins P, Watts M (2011) Global nature. In: Peet R, Robbins P, Watts M (eds) Global political ecology. Routledge, London, pp $1-48$

Ritchie H (2014) Understanding emerging discourses of Marine Spatial Planning in the UK. Land Use Policy 38:666-675

Rothwell D, Stephens T (2016) The international law of the Sea, 2nd edn. Hart Publishing, Oxford

Scott K (2015) Integrated oceans management: a new frontier in marine environmental protection. In: Rothwell D, Elferink AGO, Scott KN et al (eds) The Oxford handbook of the law of the Sea. Oxford University Press, Oxford, pp 463-490

Singh P (2018) Institutional framework for marine environmental governance. In: Solomon M, Markus T (eds) Handbook on marine environment protection. Springer, Heidelberg, pp 563-584

Singh P, Jaeckel A (2018) Future prospects of marine environmental governance. In: Solomon M, Markus T (eds) Handbook on marine environment protection. Springer, Heidelberg, pp 621-636

Steinberg PE (2001) The social construction of the ocean. Cambridge University Press, Cambridge

Stephenson J, Berkes F, Turner N et al (2014) Biocultural conservation of marine ecosystems: examples from New Zealand and Canada. Indian J Tradit Know 13(2):257-265

Tanaka Y (2015a) The international law of the sea, 2nd edn. Cambridge University Press, Cambridge

Tanaka Y (2015b) Principles of international marine environmental law. In: Rayfuse R (ed) Research handbook on international marine environmental law. Edward Elgar Publishing, Cheltenham, pp 31-56

Trouwborst A (2009) The precautionary principle and the ecosystem approach in international law: differences, similarities and linkages. Rev Euro Commun Int Environ Law 18(1):26-37

UNCLOS - United Nations Convention on the Law of the Sea (1982) 1833 U.N.T.S. 397

United Nations (2012b2012a) The United Nations Convention on the Law of the Sea (A historical perspective). Available at: http://www. un.org/Depts/los/convention_agreements/convention_historical_ perspective.htm. Accessed 8 June 2018

United Nations Economic and Social Council (2016) Study on the relationship between indigenous peoples and the Pacific Ocean. E/C.19/2016/3

Vince J (2014) Introduction: oceans governance: where have we been and where are we going? Aust J Maritime Ocean Aff 6(1):3-4

WBGU (2013) World in transition: governing the marine heritage. Wissenschaftlicher Beirat Globale Umweltveränderungen/German Advisory Council on Global Change, Berlin

Winter G (2018) International principles of marine environmental protection. In: Solomon M, Markus T (eds) Handbook on marine environment protection. Springer, Heidelberg, pp 585-606

Wirth C (2017) Danger, development, and legitimacy in East Asian Maritime Politics: securing the seas securing the state. Routledge, London

Zacharias M (2014) An introduction to governance and international law of the oceans. Routledge, London

Open Access This chapter is licensed under the terms of the Creative Commons Attribution 4.0 International License (http://creativecommons. org/licenses/by/4.0/), which permits use, sharing, adaptation, distribution and reproduction in any medium or format, as long as you give appropriate credit to the original author(s) and the source, provide a link to the Creative Commons license and indicate if changes were made.

The images or other third party material in this chapter are included in the chapter's Creative Commons license, unless indicated otherwise in a credit line to the material. If material is not included in the chapter's Creative Commons license and your intended use is not permitted by statutory regulation or exceeds the permitted use, you will need to obtain permission directly from the copyright holder. 